\title{
Analysis on Microbial Community Structure Change for Low Permeability Reservoirs in Daqing Oil Field at Different Days in Outdoor
}

\author{
G.L. REN ${ }^{1, a}$, J.L. WANG ${ }^{1, b}, Y . X L^{2, c}$, H.M. YUAN ${ }^{1, d}$, J.J. LE ${ }^{3, e}$, J.Y. ZHANG ${ }^{3, f}$, \\ L.L. BAl ${ }^{3, g}$, X.H. $\mathrm{CHEN}^{3, \mathrm{~h}}, \mathrm{H} . \mathrm{ZHANG}^{1, \mathrm{l}}$ and Y.H. HUANG ${ }^{1, \mathrm{j},{ }^{,}}$
}

\author{
${ }^{1}$ School of Biotechnology, Daqing Normal University, Daqing, Heilongjiang 163712, China \\ ${ }^{2}$ Institute of Geological Processes, Qingxin Oilfield Company, Ltd., Suihua, Heilongjiang 151413, \\ China
}

${ }^{3}$ Exploration and Development Research Institute, Daqing Oilfield Company, Ltd., Daqing, Heilongjiang 163712, China

arengl272@163.com, ${ }^{b}$ wangjinlong_08@163.com, ${ }^{\text {LLiyx@petrochina.com.cn, }{ }^{d} y u a n h m 1979 @ 163 . c o}$

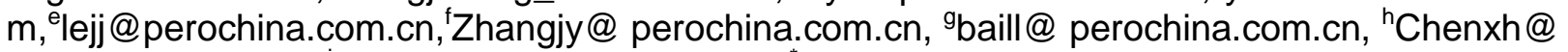
perochina.com.cn,'xuanlingmu123@sina.com, “corresponding author: jrengl272@aliyun.com

Keywords: Microbial Community Structure; Low Permeability Reservoirs; Different Days.

Abstract. To gain a better understanding the difference on microbial community structure for low permeability reservoirs in Daqing Oil Field at different days in outdoor, we constructed the 16SrDNA gene clone library for different days' samples respectively. The results showed that the dominant microbes of zero days' sample are uncultured Acinetobacter sp. (42\%), uncultured Clostridia bacterium(21\%) and Bacillus sp. (12\%); the dominant microbes of two days' sample are uncultured Acinetobacter sp. (53\%), uncultured Clostridia bacterium (13\%) and Bacillus sp. $(10 \%)$; the dominant microbes of four days' sample are uncultured Acinetobacter sp. (62\%), uncultured Clostridia bacterium (10\%), Bacillus sp.(9\%) and uncultured Klebsiella sp.(8\%); the dominant microbes of 6 days' sample are uncultured Acinetobacter sp. (70\%) and uncultured Klebsiella sp.(10\%). The numbers of uncultured Acinetobacter sp. and uncultured Klebsiella sp. are gradually increased, the numbers of uncultured Clostridia bacterium, Bacillus sp., Ochrobactrum sp. and Pseudomonas sp. are gradually decreased. It is supposed to provide a dependable basis for the importance for analysing microbial community structure of oil reservoir without delay.

\section{Introduction}

Microbial Enhanced Oil Recovery (MEOR) technology that has rapidly developed for simple process, safety operation, non-pollution for the environment and low cost. Bio-gas, bio-polymers, inorganic salts and so on were precipitated in the process of growth, reproduction and metabolism of microbes after the injection of microbes or activation of origin microbes ${ }^{[1]}$. Many foreign countries such as the United States, Romania and so on have made a lot of field test of microbial enhanced oil recovery and achieved some good effects ${ }^{[2,3]}$. In China Dagang, Shengli, Daqing Oil Field and so on carried out some researches from the 1960's in this area and increased microbial enhanced oil recovery pilot $10 \% \sim 30 \%{ }^{[4,5]}$. Compared with a variety of chemical profile modification, microbial profile modification overcomes some problems. Therefore, it is significant to explore new technologies to further enhance oil recovery and select representative blocks to carry out microbial profile modification field tests in oil reservoirs.

But MEOR technology is still relatively small scale, and the supporting technology needs further study. Analysis of microbial community structure is a key for MEOR. The sequencing technology based on 16S rDNA for its unique advantages is increasingly used in microbial enhanced oil recovery technology research ${ }^{[6,7]}$. Orphan et al ${ }^{[8]}$ analyzed the microbial community of California high temperature, sulfur-rich reservoirs. Grabowski ${ }^{[9]}$ obtained the microbial community diversity in Canadian low-temperature, low salinity reservoirs by using 16S rDNA gene clone library. She et $\mathrm{al}^{[10]}$ revealed microbial community structure of reservoirs by PCR-DGGE analysis of water samples in Xinjiang Karamay oil field. Zhang et al ${ }^{[11]}$ analyzed the microbial community diversity of reservoirs after polymer flooding by ARDRA in Daqing oil field. 
In this study, in order to assess the importance of analysing the microbial community structure after sampling immediately, we extracted genomic DNA of different days' samples on low permeability oil reservoirs in Daqing oilfield. Then, we amplified $16 \mathrm{~S}$ rDNA gene from each sample, constructed 16S rDNA gene clone libraries of four samples. By analysing the difference of microbial community structure for the four $16 \mathrm{~S}$ rDNA gene clone libraries, Our study provide a dependable basis for the importance for analysing microbial community structure of oil reservoir without delay.

\section{Materials and Methods}

Materials. The experimental production fluid was collected from the CHAO 60-124 well in the CHAO 50 Block of low permeability oil reservoirs in Daqing Oil Field. Experimental equipments include the low temperature refrigerated centrifuge, MyCycler gradient PCR system, incubator, ultra low temperature freezer, Bio-Imaging System and so on.

DNA extraction. The protocol of microbial total genomic DNA extraction of low permeability oil reservoirs in Daqing oilfield was described previously ${ }^{[12]}$. The extracted genomic DNA was stored in $-20^{\circ} \mathrm{C}$.

PCR amplification. The PCR amplification was performed with universal primers for 16S rDNA gene of bacteria ${ }^{[13]}$. The PCR mixture contained: $2 \mu$ cell suspension, $0.75 \mu \mathrm{M}$ of each primer, 12.5 $\mu 1$ Premix Taq Version 2.0, and molecular biology grade water to a final volume of $25 \mu$. Bacterial PCR was performed in MyCycler gradient PCR system as follows: $95^{\circ} \mathrm{C}$ for $10 \mathrm{~min}$; 35 cycles at $94^{\circ} \mathrm{C}$ for $45 \mathrm{~s}, 54^{\circ} \mathrm{C}$ for $45 \mathrm{~s}, 72^{\circ} \mathrm{C}$ for $2 \mathrm{~min} ; 72^{\circ} \mathrm{C}$ for $10 \mathrm{~min}$. PCR products were checked by $1.0 \%$ agarose gel electrophoresis.

Construction of $16 \mathrm{~S}$ rDNA gene clone library. The recovery fragment of amplified 16S rDNA gene was connected with pMD-19T vector (Promega). The ligated products were transformed into E.coli competent cells; Cells $(50 \mu \mathrm{l})$, incubated for $45 \mathrm{~min}$ at $37^{\circ} \mathrm{C}$, were spread on LB plates containing Ampicillin $(100 \mu \mathrm{g} / \mathrm{ml})$, IPTG $(50 \mathrm{mM})$, and X-Gal $(80 \mu \mathrm{g} / \mathrm{ml})$. One hundred putative clones (white) from each plate were selected to sequence.

Blast and construction of phylogenetic trees. The 16S rDNA sequences were analyzed by GenBank database; the NJ method construction of phylogenetic trees used MEGA 4.1 software ${ }^{[14]}$.

\section{Results and Analysis}

The results of microbial total genomic DNA extraction and PCR amplification. In order to construct $16 \mathrm{~S}$ rDNA gene clone library, microbial total bacteria genomic DNA of four days' samples were extracted. The results shown in Fig.1 showed that the genomic DNA fragments were more than $2.3 \mathrm{~kb}$. Then, the PCR amplification was performed with universal primers for $16 \mathrm{~S}$ rDNA gene of bacteria. PCR products' fragments of $16 \mathrm{~S}$ rDNA gene were about 1500bp(as shown Fig.2).

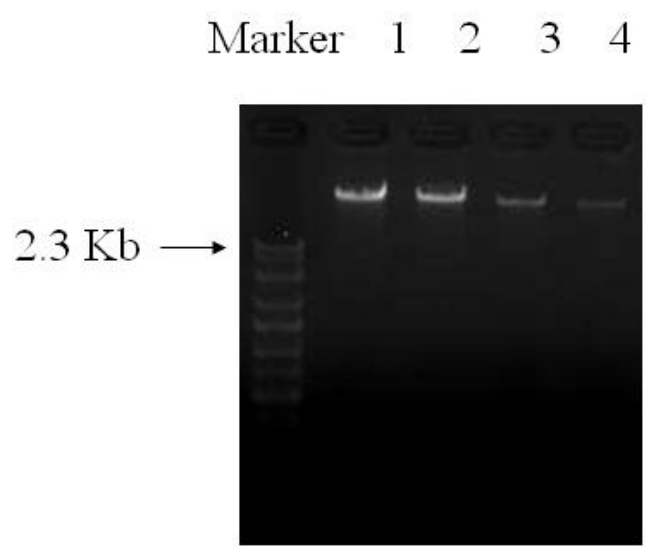

Marker: Lambda DNA/HindIII , 1: zero days, 2: two days, 3: four days, 4: six days.

Fig.1 The genomic DNA extraction 


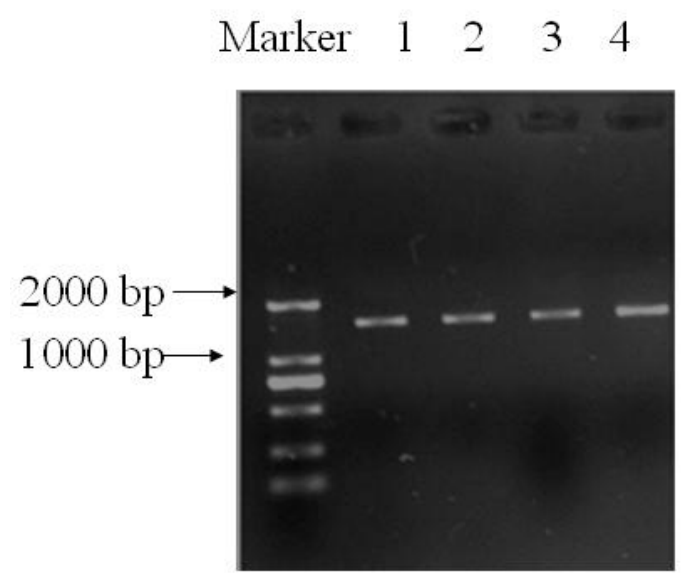

Marker: DL2000, 1: zero days, 2: two days, 3: four days, 4: six days.

Fig.2 The PCR products of 16S rDNA gene

The results of construction and analysis for $16 \mathrm{~S}$ rDNA gene clone library. The recovery fragments of amplified 16S rDNA gene were connected with pMD-19T vectors respectively. The ligated products were transformed into E.coli competent cells. Four gene clone libraries were constructed suceessfully(the results aren't shown). One hundred positive clones were sequenced and the sequences were analyzed using Nucleotide BLAST software. As Tab.1 shown,We obtained eight operational taxonomic units (Operational Taxonomic Unit, OUT) by the BLAST results of $16 \mathrm{~S}$ rDNA gene sequences from zero days' sample, of which four OUTs is the dominant groups (including more than eight clones). The dominant microbes of zero days' sample are uncultured Acinetobacter sp. (42\%), uncultured Clostridia bacterium(21\%), Bacillus sp. (12\%) and Ochrobactrum sp.(9\%). As Tab.2 shown, we obtained eight operational taxonomic units (Operational Taxonomic Unit, OUT) by the BLAST results of 16S rDNA gene sequences from two days' sample, of which three OUTs is the dominant groups. The dominant microbes of two days' sample are uncultured Acinetobacter sp. (53\%), uncultured Clostridia bacterium(13\%) and Bacillus sp. (10\%). As Tab.3 shown, we obtained seven operational taxonomic units (Operational Taxonomic Unit, OUT) by the BLAST results of $16 \mathrm{~S}$ rDNA gene sequences from four days' sample, of which four OUTs is the dominant groups (including more than eight clones). The dominant microbes of four days' sample are uncultured Acinetobacter sp. (62\%), uncultured Clostridia bacterium(10\%) , Bacillus sp. (9\%) and uncultured Klebsiella sp.(8\%). As Tab.4 shown, we obtained six operational taxonomic units (Operational Taxonomic Unit, OUT) by the BLAST results of 16S rDNA gene sequences from six days' sample, of which two OUTs is the dominant groups (including more than eight clones). The dominant microbes of six days' sample are uncultured Acinetobacter sp. (70\%) and uncultured Klebsiella sp.(10\%). 
Table 1 Clone library analysis of the 16S rDNA genes of zero days' sample microorganism Similarity

Type Clone number GenBank Phylogenetically closest related organism Accession number phylogenetically identified closest related organism $1 \%$

\begin{tabular}{|c|c|c|c|}
\hline \multicolumn{4}{|c|}{$1 \%$} \\
\hline W1 & 42 & EU050693 & Uncultured Acinetobacter sp. clone DQ311-68 \\
\hline W2 & 21 & JX505406 & Uncultured Clostridia bacterium clone \\
\hline $1-159$ & $99 \%$ & & \\
\hline W3 & 12 & EU740977 & Bacillus sp. W1 \\
\hline W4 & 9 & DQ989292 & Ochrobactrum sp. 1605 \\
\hline W5 & 6 & AY692045 & Uncultured Arcobacter sp. clone I62 \\
\hline W6 & 5 & AJ704793 & Pseudomonas sp. ws15 \\
\hline $\begin{array}{c}\text { W7 } \\
\text { Bog2-47 }\end{array}$ & 4 & JF817517 & Uncultured Geobacter sp. clone \\
\hline W8 & 1 & FJ268986 & Uncultured Klebsiella sp. clone IITR RCP25 \\
\hline
\end{tabular}

Table 2 Clone library analysis of the 16S rDNA genes of two days' sample microorganism

Type Clone number GenBank Phylogenetically closest related organism
Similarity Accession number phylogenetically identified closest related organism $1 \%$

\begin{tabular}{|c|c|c|c|}
\hline & \multicolumn{3}{|c|}{$1 \%$} \\
\hline W1 & 53 & EU050693 & Uncultured Acinetobacter sp. clone DQ311-68 \\
\hline W2 & 13 & JX505406 & Uncultured Clostridia bacterium clone \\
\hline 159 & $99 \%$ & & \\
\hline W3 & 10 & EU740977 & Bacillus sp. W1 \\
\hline W4 & 7 & FJ268986 & Uncultured Klebsiella sp. clone IITR RCP25 \\
\hline W5 & 6 & DQ989292 & Ochrobactrum sp. 1605 \\
\hline W6 & 6 & AY692045 & Uncultured Arcobacter sp. clone I62 \\
\hline W7 & 4 & JF817517 & Uncultured Geobacter sp. clone \\
\hline $\begin{array}{c}\text { Bog2-47 } \\
\text { W8 }\end{array}$ & $190 \%$ & AJ704793 & Pseudomonas sp. ws 15 \\
\hline & & & \\
\hline
\end{tabular}


Table 3 Clone library analysis of the 16S rDNA genes of four days' sample microorganism Similarity

Type Clone number GenBank Phylogenetically closest related organism

\begin{tabular}{|c|c|c|c|}
\hline & & 19 & \\
\hline W1 & 62 & EU050693 & Uncultured Acinetobacter sp. clone DQ311-68 \\
\hline $99 \%$ & & & \\
\hline W2 & 10 & JX505406 & Uncultured Clostridia bacterium clone \\
\hline Pad-159 & $99 \%$ & & \\
\hline W3 & 9 & EU740977 & Bacillus sp. W1 \\
\hline $98 \% \quad$ W4 & 8 & FJ268986 & Uncultured Klebsiella sp. clone IITR RCP25 \\
\hline $93 \%$ W5 & 6 & DQ989292 & Ochrobactrum sp. 1605 \\
\hline $\begin{array}{l}100 \% \\
90 \%\end{array}$ & 4 & AY692045 & Uncultured Arcobacter sp. clone I62 \\
\hline $\begin{array}{c}\text { W7 } \\
\text { MFCBog2-47 }\end{array}$ & $190 \%$ & JF817517 & Uncultured Geobacter sp. clone \\
\hline
\end{tabular}

Table 4 Clone library analysis of the 16S rDNA genes of zero days' sample microorganism Similarity

Type Clone number GenBank Phylogenetically closest related organism

\begin{tabular}{|c|c|c|c|}
\hline & & 10 & \\
\hline W1 & 70 & EU050693 & Uncultured Acinetobacter sp. clone \\
\hline DQ311-68 & $99 \%$ & & \\
\hline W2 & 10 & FJ268986 & Uncultured Klebsiella sp. clone IITR RCP25 \\
\hline $93 \%$ & & & \\
\hline W3 & 7 & JX505406 & Uncultured Clostridia bacterium clone \\
\hline Pad-159 & $99 \%$ & & \\
\hline W4 & 6 & EU740977 & Bacillus sp. W1 \\
\hline $\begin{array}{ll}98 \% & \\
& \text { W5 }\end{array}$ & 6 & AY692045 & Uncultured Arcobacter sp. clone I62 \\
\hline $\begin{array}{ll}90 \% & \\
100 \% & \text { W6 }\end{array}$ & 1 & DQ989292 & Ochrobactrum sp. 1605 \\
\hline
\end{tabular}

The microbial community structure change characteristics of different days. The results of four different samples' $16 \mathrm{~S}$ rDNA gene clone libraries showed that uncultured Acinetobacter sp. accouted for $42 \%, 53 \%, 62 \%$ and $70 \%$ respectively, uncultured Clostridia bacterium accouted for $21 \%, 13 \%, 10 \%$ and $7 \%$ respectively, Bacillus sp. W1 accouted for $12 \%, 10 \%, 9 \%$ and $6 \%$ respectively, Ochrobactrum sp. 1605 accouted for $9 \%, 6 \%, 4 \%$ and $1 \%$ respectively, uncultured Klebsiella sp. accouted for $1 \%, 7 \%, 8 \%$ and $10 \%$. These results showed that the numbers of uncultured Acinetobacter sp. and uncultured Klebsiella sp. are gradually increased, the numbers of uncultured Clostridia bacterium, Bacillus sp., Ochrobactrum sp. and Pseudomonas sp. are gradually decreased, and the numbers of uncultured Arcobacter sp. aren't changed. 


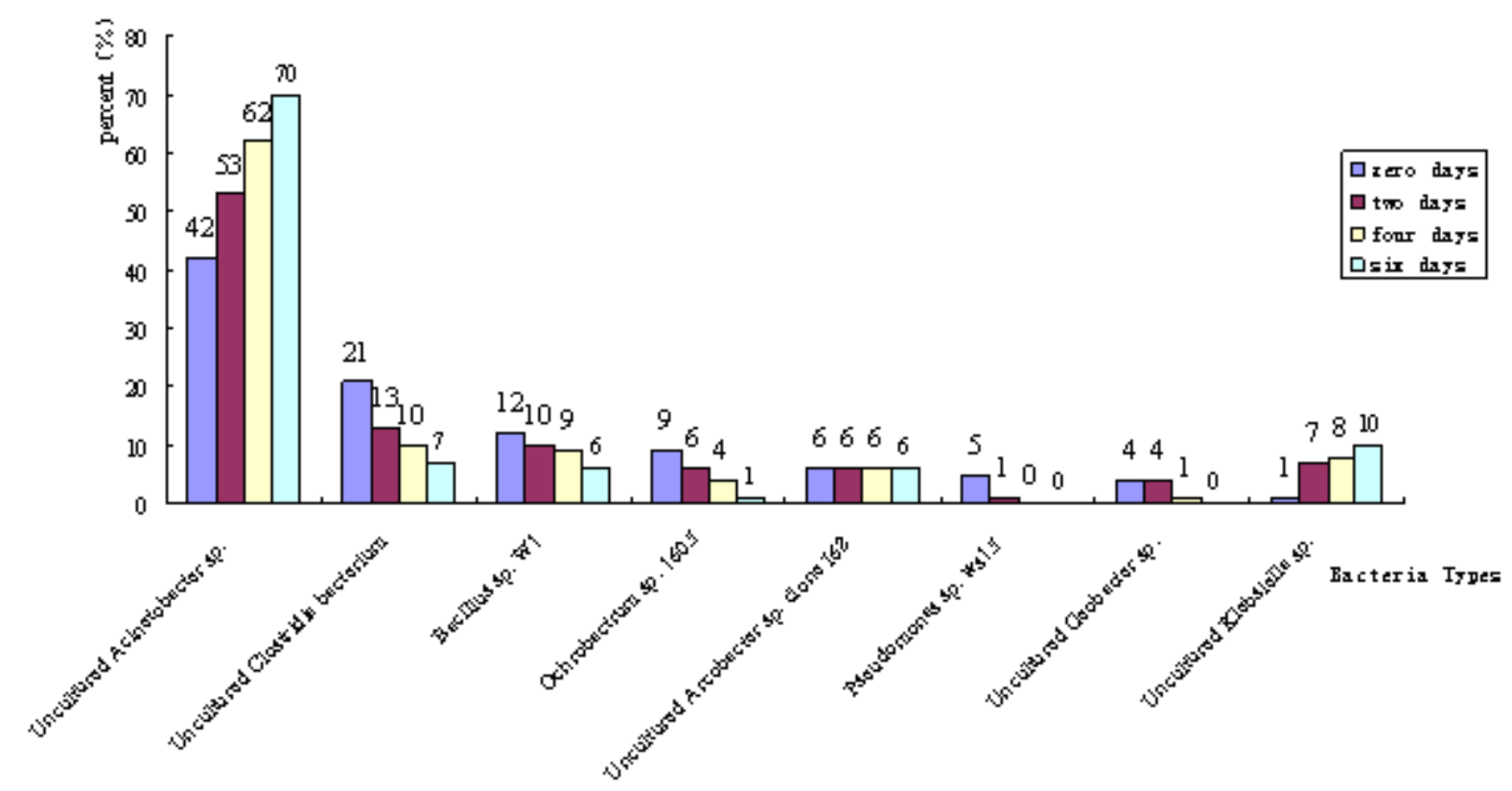

Fig.3 The percent of different bacteria types on different days

\section{Conclusions}

With the developement of Microbial Enhanced Oil Recovery (MEOR) technology for many years, microbial community structure has undergone great changes. As a lot of unknown species is hard to cultrue, we haven't known their functions. Analysis of microbial community structure is a key for MEOR. It maybe inaccurate if we couldn't construct 16S rDNA gene clone library immediately. The results showed that some bacterial numbers are increased, some bacterial numbers are decreased, some bacterial numbers aren't changed. Compared with microbial community structure of zero days' sample, microbial community structure of six days' sample has changed largely. The dominant microbes of zero days' sample which are Acinetobacter sp. (42\%), uncultured Clostridia bacterium(21\%) , Bacillus sp. (12\%) and Ochrobactrum sp.(9\%).have changed into uncultured Acinetobacter sp. (70\%) and uncultured Klebsiella sp.(10\%) after six days. The types of bacteria have reduced to six kinds. But percent of some dominant microbes was increased. Our study provide a dependable basis for the importance of analyzing microbial community structure of oil reservoir without delay.

\section{Acknowledgements}

This work is supported by Doctoral Fund of Daqing Normal University(No.12ZR06), Youth Science Fund Project of Heilongjiang Province (No.QC2011094) and Science and Technology Plan Program of Daqing city(No. szdfy-2015-66). The authors would like to thank her collaborators for their help.

\section{References}

[1] L.R. Brown: submitted to Curr Opin Microbiol (2010).

[2] M. Siegert, J. Sitte and A. Galushko: submitted to Adv Biochem Eng Biotechnol (2014).

[3] C. Coman, C.M. Chiriac and M.S. Robeson: submitted to Front Microbiol (2015).

[4] Y.H. She, X.L. Zhang and F. Zhang: submitted to Acta Microbiologica Sinica (2005).

[5] M.T. Bao, X.P. Kong and Y.T. Song: submitted to Journal of the University of Petroleum (2004).

[6] G. Voordouw, S.M. Armstrong and M.F. Reimer: submitted to Applied and Environmental Microbiology (1996).

[7] H. Li, S.Z. Yang and B.Z. Mu: submitted to Current Microbiology (2007). 
[8] V.J. Orphan, L.T. Taylor, and D. Hafenbradl: submitted to Appl Environ Microbiol (2000).

[9] A. Grabowski, O. Nercessian and F. Fayolle: submitted to FEMS Microbiol Ecol (2005).

[10] Y.H. She, F. Zhang and T.S. Xiang: submitted to Acta Ecol Sin (2005).

[11] X.M. Zhang, Y.H. She and J.F. Huang: submitted to Chin J Appl Environ Biol (2008).

[12] Y.H. Huang, H.M. Yuan and X.L.Wu: submitted to JOURNAL OF DAQING PETROLEUM INSTITUTE (2009).

[13] G.L. Ren, L.N. Qu and J.J. Le: submitted to JOURNAL OF DAQING PETROLEUM INSTITUTE (2011).

[14] G.L. Ren, J.X. Xu and J. WANG: submitted to JOURNAL OF NORTHEAST PETROLEUM INSTITUTE (2014) 